\title{
The potential role of hydrogen energy in India and Western Europe
}

\author{
Bas van Ruijven ${ }^{\mathrm{a}, *}$, Lakshmikanth Hari ${ }^{\mathrm{c}}$, Detlef P. van Vuuren ${ }^{\mathrm{b}, 1}$, Bert de Vries ${ }^{\mathrm{a}, \mathrm{b}, 2}$ \\ a Department of Science, Technology and Society, Copernicus Institute for Sustainable Development and Innovation, Utrecht University, \\ Heidelberglaan 2, 3584 CS Utrecht, The Netherlands \\ ${ }^{\mathrm{b}}$ MNP-Netherlands Environment Assessment Agency, P.O. Box 1, 3720 BA Bilthoven, The Netherlands \\ ${ }^{\mathrm{c}}$ National Institute of Industrial Engineering, Vihar Lake, Mumbai-87, India
}

Received 11 September 2007; accepted 16 January 2008

Available online 4 March 2008

\begin{abstract}
We used the TIMER energy model to explore the potential role of hydrogen in the energy systems of India and Western Europe, looking at the impacts on its main incentives: climate policy, energy security and urban air pollution. We found that hydrogen will not play a major role in both regions without considerable cost reductions, mainly in fuel cell technology. Also, energy taxation policy is essential for hydrogen penetration and India's lower energy taxes limit India's capacity to favour hydrogen. Once available to the (European) energy system, hydrogen can decrease the cost of $\mathrm{CO}_{2}$ emission reduction by increasing the potential for carbon capture technology. However, climate policy alone is insufficient to speed up the transition. Hydrogen diversifies energy imports; especially for Europe it decreases oil imports, while increasing imports of coal and natural gas. For India, it provides an opportunity to decrease oil imports and use indigenous coal resources in the transport sector. Hydrogen improves urban air quality by shifting emissions from urban transport to hydrogen production facilities. However, for total net emissions we found a sensitive trade-off between lower emissions at end-use (in transport) and higher emissions from hydrogen production, depending on local policy for hydrogen production facilities.
\end{abstract} (C) 2008 Elsevier Ltd. All rights reserved.

Keywords: Hydrogen energy; India/Europe; Scenario analysis

\section{Introduction}

Hydrogen energy is often mentioned as a potential solution for several challenges that the global energy system is facing. The first advantage is the fact that hydrogen use results in nearly zero emissions at end-use, thus improving air quality. Secondly, hydrogen opens up the possibility of (decentralised) production on the basis of a variety of fuels, diversifying energy supply. The latter may contribute to reduce the dependence on imported oil (Dunn, 2001; Lovins, 2003). Hydrogen energy can also play an important role in the mitigation of greenhouse gas emissions (Barreto et al., 2003; Edmonds et al., 2004; van Ruijven et al., 2007). However, the required technology is

\footnotetext{
*Corresponding author. Tel.: + 31302537686 ; fax: + 31302537601 .

E-mail addresses: b.j.vanruijven@uu.nl (B. van Ruijven), hlkanth@nitie.edu (L. Hari), detlef.van.vuuren@mnp.nl (D.P. van Vuuren), bert.de.vries@mnp.nl (B. de Vries).

${ }^{1}$ Tel.: + 31302742046 ; fax: + 31302744464 .

${ }^{2}$ Tel.: + 31302743533 ; fax: + 31302744464 .
}

currently only emerging, hydrogen is still more expensive than other options and the infrastructure for widespread use still needs to be developed.

The future of hydrogen therefore depends critically on whether the above-mentioned barriers are reduced. This is partly determined by the context of the system in which hydrogen is introduced; we here focus on the difference between energy systems in developed and developing countries. This difference is, for instance, important for the reasons for making a transition. For developed regions, issues like competitiveness (being the first), greenhouse gas emission mitigation and energy security play a major role (McDowall and Eames, 2006). For developing regions, the potential to reduce air pollution emissions and improve energy security may be more important. Barriers are also likely to be different. While the affordability of hydrogen energy technology may be a more limiting factor in developing countries than in developed countries, the rapid growth of infrastructure in some developing countries (China and India) may create important opportunities. 
The evolution of the world energy system is complex, which is an argument to use models in the exploration of alternative pathways. However, at the global scale, such models are aggregated and might not deal effectively with regional differences. Hence, one should investigate the regional outcomes in more detail. In this article, we explore the potential role of hydrogen energy in two selected regions: India and Western Europe. ${ }^{3}$ The focus on only two regions implies that we are able to account for available information on the local situation. These two specific regions were chosen because earlier research showed that Western Europe might become an early adopter of hydrogen energy (van Ruijven et al., 2007), while India is one of the first (high-growth) developing countries that is seriously looking at hydrogen energy (Bist, 2006). We analyse the impact of hydrogen on the main arguments in its favour: climate policy, energy security and urban air pollution, using scenario results for demand, production and system structure as modelled in the TIMER global energy model (de Vries et al., 2001; van Vuuren et al., 2006). The aim of this analysis is to further specify and differentiate the potential role of hydrogen in the context of different energy systems.

In this paper, Section 2 provides a brief overview of existing energy scenarios for India and Western Europe. Section 3 describes the main drivers and barriers for hydrogen energy and their relevance for both regions. Section 4 discusses the current research and planning on hydrogen energy in both regions. Section 5 focuses on the modelling of hydrogen energy systems and Sections 6 and 7 discuss the results of the model simulations and the impact of hydrogen on its main driving arguments. Section 8 finalises the paper with a discussion and conclusion.

\section{Energy scenario literature for India and Western Europe}

\subsection{Energy scenarios}

By comparing available regional energy scenarios for India and Western Europe it is possible to obtain a better insight in the energy system context of these specific regions. A recently published study by the Indian Planning Commission on Integrated Energy Policy (Planning Commission, 2006) explores the future development of the Indian energy system using two economic growth scenarios. A broader set of four scenarios was published in 2003, implementing the IPCC-SRES scenarios for India, using two axes of possible future developments: high and low market integration and centralised and decentralised governance (Shukla et al., 2003). The IEA World Energy Outlook (WEO) 2006 provides two energy scenarios on the basis of a single socio-economic projection: a reference and a policy scenario (IEA, 2006).

\footnotetext{
${ }^{3}$ For the geographical definition of this region, see: www.mnp.nl/image.
}

For Europe ${ }^{4}$ several scenario studies have been published as well, describing a broad range of possible energy futures. We here limit the comparison to the IEA World Energy Outlook (IEA, 2006) and a set of European baseline scenarios from the PRIMES model (Mantzos et al., 2004). The latter explores the impact of different levels of economic growth, energy prices and policy options on energy technologies and transport modes.

The baseline scenario for the this study is the second OECD Environmental Outlook baseline scenario: TIMER OECD-EO (Kram and Bakkes, 2006). This scenario assumes no new explicit policies; it involves continuation of current policies and implicitly assumes the existence of an environmental Kuznets curve on emission factors of developing countries. With respect to energy, it is based on the IEA WEO scenario (IEA, 2004), which is regarded a medium scenario on energy supply and demand. Below, we compare the energy scenarios for India and Europe with the TIMER OECD-EO scenario. We limit this comparison to the period until 2030, because this is the time horizon of most discussed scenario studies. However, in the rest of this article, we use a time horizon up to the year 2050.

\subsection{Economy and population}

Economic projections for India are characterised by high GDP growth rates, varying between $4 \%$ per year in the $I B 2$ Self-reliance scenario (Shukla et al., 2003) and the IEAWEO and up to 9\% per year in IAI High Growth (Shukla et al., 2003) and the Planning Commission scenarios. In absolute terms, this corresponds to an increase in GDP from 467 billion $\mathrm{USD}_{1995} / \mathrm{yr}$ in 2000 to a range of $1750-5600$ billion $\mathrm{USD}_{1995} / \mathrm{yr}$ in 2030 . In the same period, the Indian population is expected to grow by about $1.1 \%$ per year, to a total of 1.4 billion people in 2030 (IEA, 2006; Planning Commission, 2006). This means that growth rates for GDP per capita are lower than for total GDP: between $3 \%$ and $7 \%$ per year, or an increase from 460 to $1240-3800$ $\mathrm{USD}_{1995}$ per capita per year. The TIMER OECD-EO scenario is in the middle of this range, projecting a GDP per capita of $2400 \mathrm{USD}_{1995} / \mathrm{yr}$ in 2030.

For Western Europe, economic growth projections decrease from $2.3 \%$ (2004-2015) to $1.8 \%$ (2015-2030) per year in the IEA-WEO and vary between $1.9 \%$ and $2.6 \%$ per year in the PRIMES study. In absolute terms, the Western European GDP is projected to increase from 9000 billion $\mathrm{USD}_{1995} / \mathrm{yr}$ in the year 2000 to $18,000-23,000$ billion $\mathrm{USD}_{1995} / \mathrm{yr}$ in 2030 . Population growth estimates for Europe are in the range of $0.1-0.2 \%$ per year,

\footnotetext{
${ }^{4}$ One particular issue with studies on Europe is the variation in geographical definitions. Official European Union studies often use the definitions of EU15 and EU25 countries, the IEA uses OECD Europe as it is at this moment (including several Eastern European countries and Turkey) and the TIMER/IMAGE model includes the region of OECD Europe as it was around the year 2000 (comparable to EU15 plus Norway and Switzerland) and the region of Eastern Europe (together these regions are comparable to the EU25).
} 
increasing from currently 380 million people to $390-415$ million people in 2030. This implies per capita GDP growth projections of $1.7-2.7 \%$ per year, or in absolute terms from $27,000 \mathrm{USD}_{1995} / \mathrm{yr}$ per capita in 2000 to $45,000-56,000$ $\mathrm{USD}_{1995} / \mathrm{yr}$ in 2030 . The TIMER OECD-EO scenario is on the lower bound of this range.

\subsection{Energy}

For India, the comparison of energy use projections is somewhat complicated by the fact that some studies include non-commercial energy, while others do not. The Planning Commission projects a 5-7-fold increase of primary energy use between 2000 and 2030, excluding non-commercial energy. The other studies are more moderate, projecting TPES to increase $2-3$ fold between 2000 and 2030. The TIMER OECD-EO scenario is in line with the average of the other studies (excluding the Planning Commission), projecting a factor 2.3 increase of the total Indian energy use between 2000 and 2030 (Fig. 1, left graph).

In the Indian primary energy mix of the TIMER OECDEO scenario, coal is projected to remain dominant, followed by oil and biomass. Nuclear and renewable energy sources show a rapid increase in India, but are not projected to reach the European 2003 level by 2050 (see
Tables 1 and 2). Biomass energy, which is mainly used for cooking in rural households, made up almost $40 \%$ of the total energy use of India in the year 2000; although its share is generally expected to decline, its evolution is one of the main uncertainties in energy use projections. Currently, India already depends strongly on imports of oil and for the future it is expected that imports will increase to almost the total oil consumption in the country (Table 1). Also natural gas, which is increasingly applied in India's transport sector, is expected to be imported up to almost $90 \%$ by 2050 .

The energy scenarios for India do hardly involve any role of hydrogen. The Planning Commissions recommends the government to develop a research programme for hydrogen, as they regard it a promising energy carrier for the long-term future. The IEA-WEO 2006 expects fuel cells (running on hydrogen) to count for $1 \%$ of global electricity production by 2030 , but it does not explicitly mention the involved regions. Hydrogen application in the transport sector is indicated 'promising after 2030' (IEA, 2006). The TIMER OECD-EO scenario does not involve any hydrogen energy applications in India before 2050.

For Europe, the projections considered here provide a range of $8-27 \%$ increase in TPES in 2030 compared to 2000. The TIMER OECD-EO scenario is on bottom of this range, as it projects an increase of $10 \%$ between 2000 and
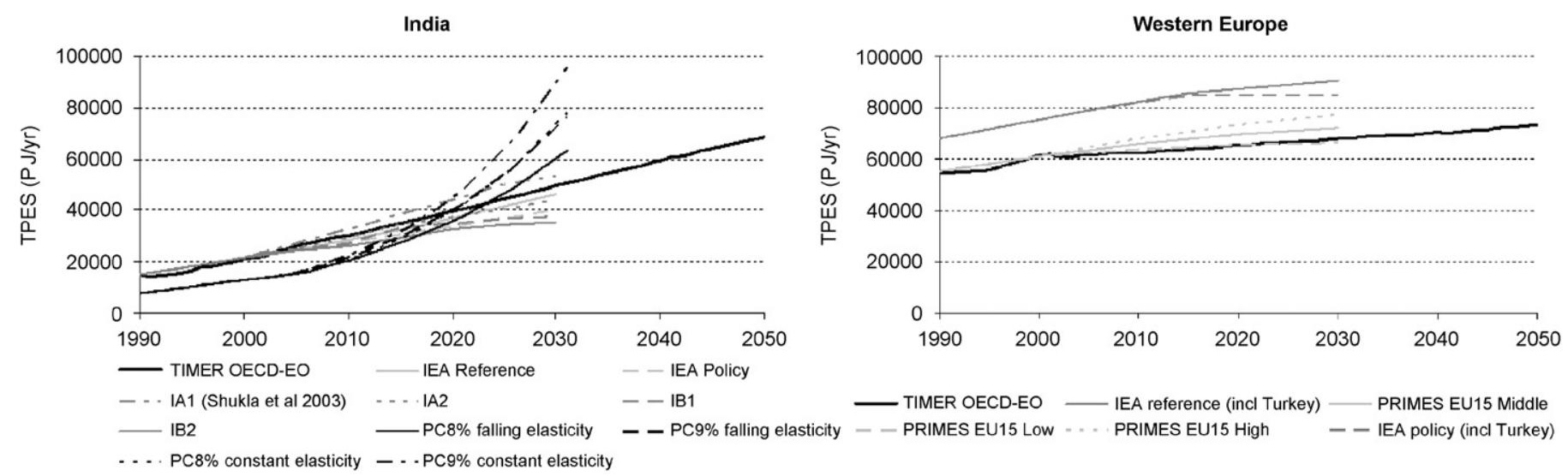

Fig. 1. Total primary energy supply in several scenarios for India and Western Europe. The different levels for Europe in 1990 are due to different regional definitions. The different levels for India are due to the exclusion of non-commercial fuels by the Planning Commission.

Table 1

Total primary energy supply in India (EJ/yr) coal oil natural gas biomass nuclear solar/wind

\begin{tabular}{|c|c|c|c|c|c|c|c|c|}
\hline India & Coal & Oil & Natural gas & Biomass & Nuclear & Solar/wind & Hydro & Total \\
\hline 2000 & 7.1 & 4.8 & 0.9 & 8.5 & 0.2 & 0.0 & 0.3 & 21.6 \\
\hline Import & $8 \%$ & $67 \%$ & & & & & & $18 \%$ \\
\hline 2030 & 22.0 & 12.2 & 2.8 & 13.6 & 1.4 & 0.1 & 0.7 & 51.8 \\
\hline Import & $8 \%$ & $91 \%$ & $50 \%$ & $7 \%$ & & & & $29 \%$ \\
\hline 2050 & 29.7 & 20.7 & 7.0 & 12.8 & 1.7 & 0.5 & 0.8 & 72.1 \\
\hline Import & $10 \%$ & $99 \%$ & $88 \%$ & $4 \%$ & & & & $41 \%$ \\
\hline
\end{tabular}

Historic data: IEA energy balances, future data: TIMER OECD Environmental Outlook scenario. Nuclear energy is converted to primary energy using $33 \%$ efficiency; numbers for solar, wind and hydro are the energy content of electricity produced. 
Table 2

Total primary energy supply in OECD Europe (EJ/yr)

\begin{tabular}{llllllrr}
\hline Western Europe & Coal & Oil & Natural gas & Biomass & Nuclear & Solar/wind & Hydro \\
\hline 2000 & 10.0 & 25.2 & 11.8 & 2.0 & 9.1 & 0.0 & 1.6 \\
Import & $46 \%$ & $55 \%$ & $41 \%$ & $1 \%$ & & 59.9 \\
2030 & 12.5 & 18.4 & 23.8 & 10.4 & 8.4 & 2.0 & 2.0 \\
Import & $72 \%$ & $57 \%$ & $59 \%$ & $48 \%$ & & 71.8 \\
2050 & 17.7 & 22.9 & 24.5 & 5.8 & 7.4 & 3.9 & 2.3 \\
Import & $66 \%$ & $61 \%$ & $65 \%$ & $23 \%$ & & $59 \%$ \\
\hline
\end{tabular}

Historic data: IEA energy balances, future data: TIMER OECD Environmental Outlook scenario. Nuclear energy is converted to primary energy using $33 \%$ efficiency; numbers for solar, wind and hydro are the energy content of electricity produced.

2030 (Fig. 1). Europe's main primary energy carriers are oil and natural gas, followed by coal and nuclear (Table 2). The high and increasing share of imported energy, especially coal and oil, indicates that indigenous resources in Europe become more expensive while being depleted. The production of renewable energy sources such as biomass, solar/wind, geothermal and hydro is projected to increase steadily.

Although the PRIMES scenario study does not foresee any role for hydrogen in the baseline scenario, the scenarios 'mainstream policy lines: energy efficiency and renewables' and 'combined policy', project a total installed capacity of about $56-58 \mathrm{GW}$ of hydrogen-based fuel cells for the EU25 in 2030 (Mantzos et al., 2004). The TIMER OECD-EO scenario does not show any hydrogen in Western Europe before 2050.

\section{Drivers and barriers for hydrogen energy in India and Western Europe}

\subsection{Drivers}

In a recent literature overview of hydrogen studies, four main drivers towards a hydrogen energy system were identified: (1) climate change, (2) energy security, (3) air pollution and (4) competitiveness (McDowall and Eames, 2006).

\subsubsection{Climate change}

India and Western Europe play different roles in the climate policy debate. The Western European energy system emits currently about $1 \mathrm{GtC} / \mathrm{yr}$, which is about $15 \%$ of the global carbon emissions from energy use. The TIMER OECD-EO scenario projects a slow increase, up to $1.2 \mathrm{GtC} / \mathrm{yr}$ in $2050(9 \%$ of the projected global carbon emissions, see Fig. 2). The European Union countries have carbon emission reduction targets under the Kyoto Protocol and the European Council accepted proposals for stringent reductions of greenhouse gas emissions (Council of the European Union, 2007).

India's emissions are currently $0.3 \mathrm{GtC} / \mathrm{yr}$ from energy use, which is $4 \%$ of the global emissions. However, future projections foresee a large increase in Indian carbon

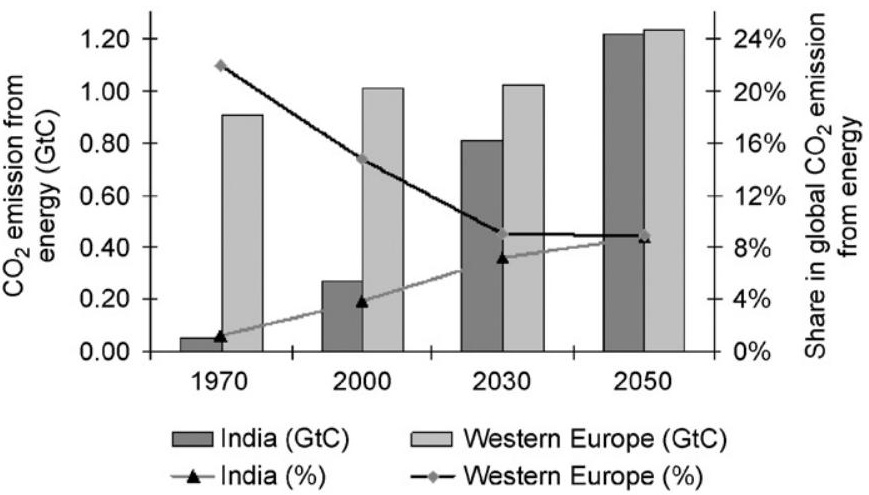

Fig. 2. $\mathrm{CO}_{2}$ emission from energy use for India and Western Europe for the TIMER OECD Environmental Outlook scenario; absolute (bars, left axis) and relative to the total global energy-based carbon emission (lines, right axis).

emissions, leading to $1.2 \mathrm{GtC} / \mathrm{yr}$ in 2050 (similar to Western Europe and 9\% of the projected global emissions, see Fig. 2). For India, no official climate policy has been adopted. Some authors (e.g. den Elzen and Meinshausen, 2005) argue that on the longer term participation of India in climate policy is needed in order to reach global stabilisation targets. However, there has been no statement by the Indian government in this direction.

In an earlier study, we found that the role of hydrogen with respect to $\mathrm{CO}_{2}$ emissions is ambiguous (van Ruijven et al., 2007). On the one hand, hydrogen can make energy systems more flexible in responding to climate policy, because it makes the option of carbon capture and sequestration available to the transport sector. On the other hand, hydrogen production from coal is the cheapest option, causing an increase in $\mathrm{CO}_{2}$ emissions on the longterm, without climate policy.

\subsubsection{Energy security}

Energy security is a relevant issue for both India and Western Europe. Fig. 3 shows the absolute trade flows and the share of imported fuels in total domestic use. India, which is currently importing over $60 \%$ of its oil, faces the potential situation that it imports all its fuels for the transport sector by 2050 . By 2030, India is projected to 


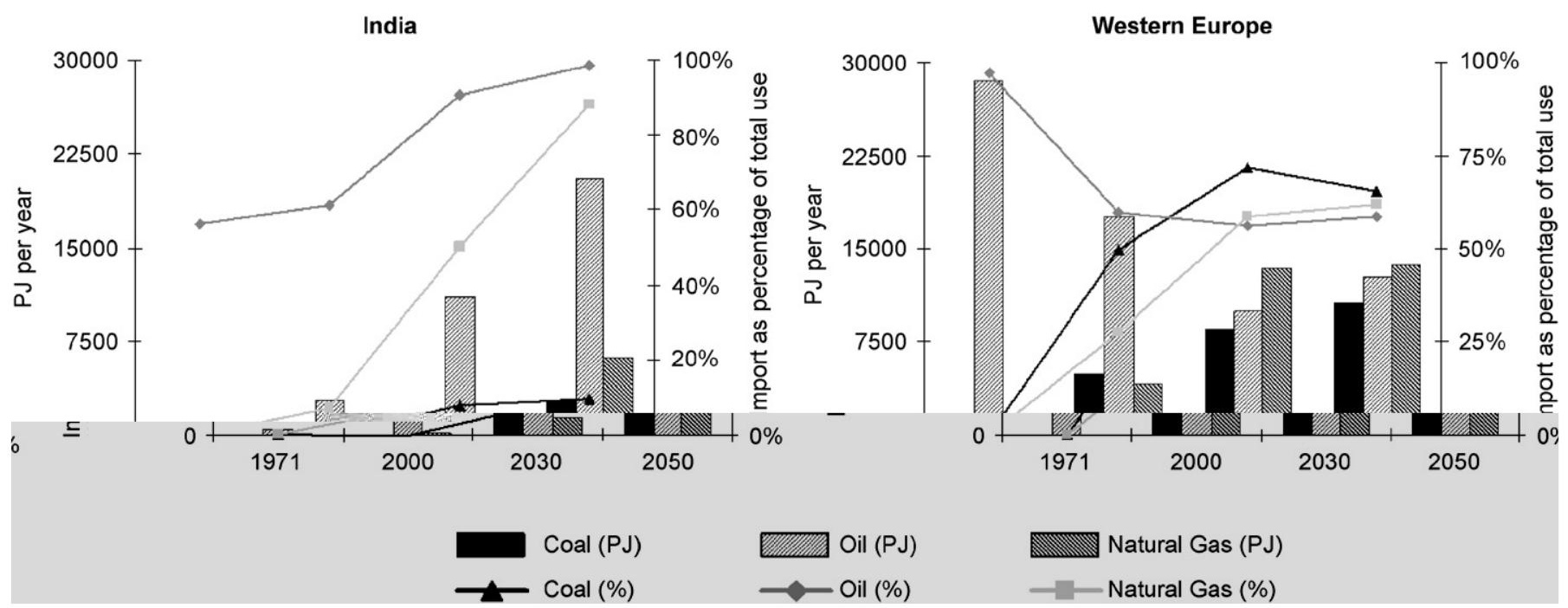

Fig. 3. Energy import for India and Western Europe, in absolute numbers (bars, left axis) and as percentage of the total inland consumption (lines, right axis) for the TIMER OECD environmental outlook scenario.

Table 3

Urban air quality in the 10 largest cities of India (left, for 2004) and Western Europe (right, for 2005), annual average concentration of $\mathrm{NO}_{2}$, $\mathrm{SO}_{2}$ and $\mathrm{PM} 10$ in $\mu \mathrm{g} / \mathrm{m}^{3}$

\begin{tabular}{|c|c|c|c|c|c|c|c|c|c|}
\hline City & $\begin{array}{l}\text { Population } \\
\text { (million) }\end{array}$ & $\mathrm{NO}_{2}$ & $\mathrm{SO}_{2}$ & PM10 & City & $\begin{array}{l}\text { Population } \\
\text { (million) }\end{array}$ & $\mathrm{NO}_{2}$ & $\mathrm{SO}_{2}$ & PM10 \\
\hline Greater Bombay & 12.59 & 19 & 7 & 77 & Paris & 9.32 & 43 & 8 & 21 \\
\hline Calcutta & 11.02 & 53 & 9 & 237 & London & 7.65 & 44 & 4 & 25 \\
\hline Delhi & 8.42 & 57 & 9 & 432 & Berlin & 3.45 & 22 & 4 & 27 \\
\hline Madras & 5.42 & 6 & 5 & 96 & Milano & 3.29 & 55 & 8 & 54 \\
\hline Hyderabad & 4.34 & 29 & 6 & 178 & Athens & 3.07 & 32 & 11 & 41 \\
\hline Bangalore & 4.13 & 61 & 7 & 173 & Madrid & 3.01 & 43 & 11 & 29 \\
\hline Ahmedabad & 3.31 & 23 & 15 & 231 & Naples & 2.95 & & & \\
\hline Pune & 2.49 & 53 & 31 & 340 & Rome & 2.70 & 41 & 2 & \\
\hline Kanpur & 2.03 & 20 & 9 & 413 & West Midlands (UK) & 2.30 & 30 & 3 & 23 \\
\hline Lucknow & 1.67 & 33 & 16 & 391 & Greater Manchester & 2.28 & 43 & 2 & 23 \\
\hline
\end{tabular}

Data for India is from Central Pollution Control Board (2004) and the Western European data are based on European Topic Centre on Air and Climate Change (2005).

import more barrels of oil per year than Western Europe; in 2050 Indian oil import is expected to be almost twice the European inflow of oil. Western Europe is already a major importer of energy, and is expected to keep importing $50-70 \%$ of its fossil energy. Natural gas imports are increasing rapidly in both regions in the TIMER OECDEO scenario. Also imports of coal are expected to keep increasing.

In an overview of hydrogen scenario studies, McDowall and Eames (2006) state that hydrogen is expected to be adopted in regions without significant indigenous oil or gas reserves, like India and Western Europe. Especially in scenarios with limited trade, the more expensive indigenous energy resources of these regions are expected to drive the use of hydrogen. We use long-term supply-costs curves of oil (and other fossil energy sources) in the TIMER model, based on Rogner (1997), but the ultimate resource size and cost estimates are still highly uncertain (e.g. Campbell,
2002). This has consequently a large influence on the future energy mix and carbon emissions (van Vuuren, 2007).

Application of hydrogen in the transport sector can potentially decrease imports of oil and increase the use of indigenous coal or gas reserves, which is relevant for both Europe and India. However, without hydrogen, Europe is already expected to import a major share of its coal and gas in the future and India's gas imports may reach $90 \%$ by 2050 as well. Production of hydrogen from these sources might cause additional imports.

\subsubsection{Urban air quality}

Urban air pollution may be a third driver for the introduction of hydrogen in the energy system, because it is a major concern in both India and Western Europe. Recent data on the concentration of air pollutants $\left(\mathrm{NO}_{2}, \mathrm{SO}_{2}\right.$ and PM10) show that urban air pollution is generally higher in India than in Europe (Table 3). Annual average 
concentrations of $\mathrm{NO}_{2}$ are slightly higher in Europe; concentrations of $\mathrm{SO}_{2}$ and especially particulate matter (PM10) are higher in India than in Europe. The trends in India reveal that in the early years of the 21 st century, several major Indian cities have improved air quality by converting three-wheelers and buses to compressed natural gas (CNG). However, since 2004 the trend is (often) increasing again (CPCB, 2004), driven by the growing amount of vehicles. The future of air quality in India is highly uncertain; on the one hand, the notion of an environmental Kuznets curve generally indicates that it might improve above a certain welfare level (Garg et al., 2003); on the other hard, the increasing number of vehicles might outweigh improvements in technology. Hydrogen energy might decrease air pollution from end-use, but emissions from hydrogen production depend on local standards.

\subsubsection{Competitiveness}

Economic competitiveness as driving argument for a transition to hydrogen energy could be important for both regions. Europe is the home market for some of the world's largest car manufacturers and energy companies, who might benefit from a common and early shift towards hydrogen. In India, the industrial and transport sectors are rapidly developing and becoming a world-leading hydrogen energy technology producer might be one of the challenges. The question whether early investors in hydrogen can capitalise their learning process is highly uncertain and beyond the scope of our model and this article.

\subsection{Barriers}

In general, the main barriers for the development of a hydrogen energy system are the development of infrastructure and the (present-day) high cost. Also safety, public acceptance and the development of codes and standards are potential obstacles for the large-scale implementation of hydrogen (McDowall and Eames, 2006).

The development of infrastructure is a major task for the implementation of hydrogen in both regions. India is currently expanding its infrastructure for natural gas (Dhar, 2007) and might have a chance for leapfrogging if these gas-pipelines could also transport hydrogen. However, the present generation of pipelines is not able to transport hydrogen. This indicates that the transition might be as difficult as in Europe, which already has a densely spread natural gas network, not suitable for the transport of pure hydrogen. Hydrogen can be mixed into existing natural gas grids up to a maximum level of $5 \%$ on energy basis (Hendriks et al., 2002), a process that might play a role in the initial phases of a transition.

The high costs of hydrogen technology may play out differently for both regions. Due to differences in GDP per capita, hydrogen energy technology is relatively more expensive for Indian consumers than for Europeans. In our model, we quantified the barriers of infrastructure development and costs (see Section 5). Our quantitative results do not deal with issues like safety and public acceptance, but the storyline for optimistic hydrogen development implicitly assumes that these issues are effectively solved.

\section{Existing research and planning for hydrogen energy systems}

\subsection{Western Europe}

One of the most recent European Union (EU) documents on hydrogen energy is the report "Hydrogen Energy and Fuel Cells, a vision for our future", presented in 2003 by the European Union High Level Group for Hydrogen and Fuel Cells. The group envisions a hydrogen-based energy system for Europe in 2050 and recommends five possible actions for the European Union: (1) establish a political framework, (2) formulate a strategic research agenda, (3) develop a deployment strategy for hydrogen, (4) develop a European roadmap for hydrogen and fuel cells and (5) found a European hydrogen and fuel cell technology partnership. The included skeleton proposal for a European hydrogen and fuel cell roadmap foresees that in the period to 2020 the main focus is on research and development, field tests and niche fleets. The group foresees hydrogen energy technology to come to full development after 2020, increasing its market penetration towards a hydrogen-oriented economy in 2050. This means that in $20205 \%$ of all new vehicles is envisioned to be hydrogen powered; in 2040 this is expected to reach the level of 35\% (European Commission, 2003). Beside this vision document, no concrete European plans towards a hydrogenbased energy system exist. The development of a hydrogen energy system is promoted by the European Union, by funding several research and pilot projects. The European Commission increased its support for hydrogen and fuel cell development to 2 billion US dollar over 4 years (Solomon and Banerjee, 2006). Currently, these projects focus mainly on technology development, but safety and infrastructure development are included as well. ${ }^{5}$ One of the most concrete and practical projects is the Clean Urban Transport for Europe (CUTE)-programme. This is a demonstration project of 27 fuel cell powered regular service buses over a period of 2 years (2004-2006) in nine European cities. The programme involves design, construction and operation of the necessary infrastructure for hydrogen production and refuelling. After the first project-period, it was decided to continue the project as HyFLEET-CUTE, operating 47 buses, including 14 $\mathrm{H}_{2}$-Internal-Combustion-Engine buses. ${ }^{6}$

\footnotetext{
${ }^{5}$ See website: http://ec.europa.eu/research/leaflets/h2/page_100_en.html.

${ }^{6}$ See websites: www.global-hydrogen-bus-platform.com and www.fuelcell-bus-club.com.
} 


\subsection{India}

Although India is a leader in the field of renewable energy in the developing world, with a dedicated Ministry of New and Renewable Energy Sources (MNES) for decades, the entry of hydrogen into the energy scene in India has been fairly recent. So far, it involves only research, development and demonstration $(\mathrm{R} \& \mathrm{D})$ projects (Solomon and Banerjee, 2006). India set up the National Hydrogen Energy Board (NHEB) in 2003 under the chairmanship of the MNES. Under the programme "Hydrogen Vision 2020", India is planning to achieve targets like one million hydrogen-fuelled vehicles on the road and a total of 1000-MW hydrogen production capacity by 2020 (Bist, 2006). The National Hydrogen Energy Road Map, a report accepted by NHEB in 2006, estimates that investments of almost 6 billion US dollar would be required: 230 million USD for R\&D; and 5.5 billion USD for creating infrastructure for hydrogen production, storage, transportation and distribution (Bist, 2006). Universities and R\&D laboratories are undertaking various projects in the field of hydrogen energy with the support from MNES. The AMM Murugappa Chettiar Research Center in Chennai is developing a biological process for the generation of hydrogen from a variety of sugar-containing industrial wastes and designing a special burner to use hydrogen for cooking. Banaras Hindu University in Varanasi has developed hydrogen-fuelled two wheelers with hydrogen stored in metal hydride tanks (Chopra, 2006). India's first hydrogen fuelling station, from which the Indian Oil Corporation plans to run at least four vehicles as part of its test programme, was officially opened in October $2006 .^{7}$

\section{TIMER hydrogen model and scenarios}

\subsection{The TIMER model}

We use the TIMER 2.0 global energy model to explore the potential role of hydrogen in the energy systems of India and Western Europe. The TIMER 2.0 model is the energy sub-model of the Integrated Model to Assess the Global Environment, IMAGE 2.4, that describes the main aspects of global environmental change (Bouwman et al., 2006). TIMER is a system-dynamics energy model that simulates year-to-year investment decisions based on a combination of bottom-up engineering information and specific rules on investment behaviour, fuel substitution and technology. TIMER 2.0 (van Vuuren et al., 2006) is an expanded version of the TIMER 1.0 model (de Vries et al., 2001), with the main differences being extension of renewable energy modelling (Hoogwijk, 2004), carbon capture and storage (Hendriks et al., 2004), hydrogen (van Ruijven et al., 2007) and a desaggregation from 17 to 26 world regions. In the TIMER 2.0 model, demand for

\footnotetext{
${ }^{7}$ See website http://www.iahe.org/News.asp?id $=23$.
}

end-use energy is related to economic activity in five sectors: industry, transport, residential, services and other. The demand formulation includes autonomous and priceinduced changes in energy-intensity. Energy supply is based on fossil fuels (coal, oil, natural gas), biomass, solar and wind power, hydropower and nuclear power. Fossiland biofuels can be traded among 26 world regions. The production of each primary energy carrier includes the dynamics of depletion and learning-by-doing.

\subsection{The TIMER- $\mathrm{H}_{2}$ model}

The TIMER- $\mathrm{H}_{2}$ model involves the production, demand, infrastructure and technology dynamics of hydrogen-related technologies (Fig. 4). In the model, hydrogen can be produced from fossil energy sources (eventually including carbon capture and storage, CCS), biomass, electricity, solar thermal and nuclear heat. Hydrogen production costs are based on capital costs, O\&M costs, fuel costs and (if relevant) $\mathrm{CO}_{2}$ capture and sequestration costs. Hydrogen can be used in five end-use sectors: industry, transport, residential, services and other in which it competes with other secondary fuels. The costs of energy services from hydrogen for the end-user are the sum of hydrogen production costs, end-use capital ${ }^{8}$ (fuel cell) and infrastructure costs. The market share of hydrogen is determined by the differences in relative costs of an energy service on the basis of hydrogen and on the basis of other energy carriers. The total demand for hydrogen equals the market share multiplied by the sectoral energy demand. Subsequently, hydrogen demand is met through investments into hydrogen production capital. Finally, there is a feedback loop from technological learning: hydrogen production capital costs decline with increasing cumulative installed capacity. A more detailed description of this model can be found in van Ruijven et al. (2007).

The role of drivers and barriers for hydrogen in the model, as discussed in Section 3, is indicated in Fig. 4. The drivers are mainly related to the impact of hydrogen on the energy system: increasing the options for CCS, replacing oil in the transport sector and decreasing emissions of $\mathrm{NO}_{x}$, $\mathrm{SO}_{2}$ and particulate matter. Barriers are mainly implemented in the form of costs: both the (initially high) cost for hydrogen technologies, but also the costs of infrastructure and distribution. With respect to infrastructure development, the model simulates a delay for the construction of hydrogen production capacity and limits the production options in early stages of hydrogen deployment. To be more specific: in the first phase, hydrogen for stationary applications is only produced from small-scale steam methane reforming (SMR) technology. For the transport sector, large-scale production (from all other energy sources) is possible, but transport of hydrogen takes place by (expensive) trucks. If demand for hydrogen increases,

\footnotetext{
${ }^{8}$ The costs of the Fuel Cell (incl. stacks) are annualised over the economic lifetime of capital in the transport sector: 8 years.
} 


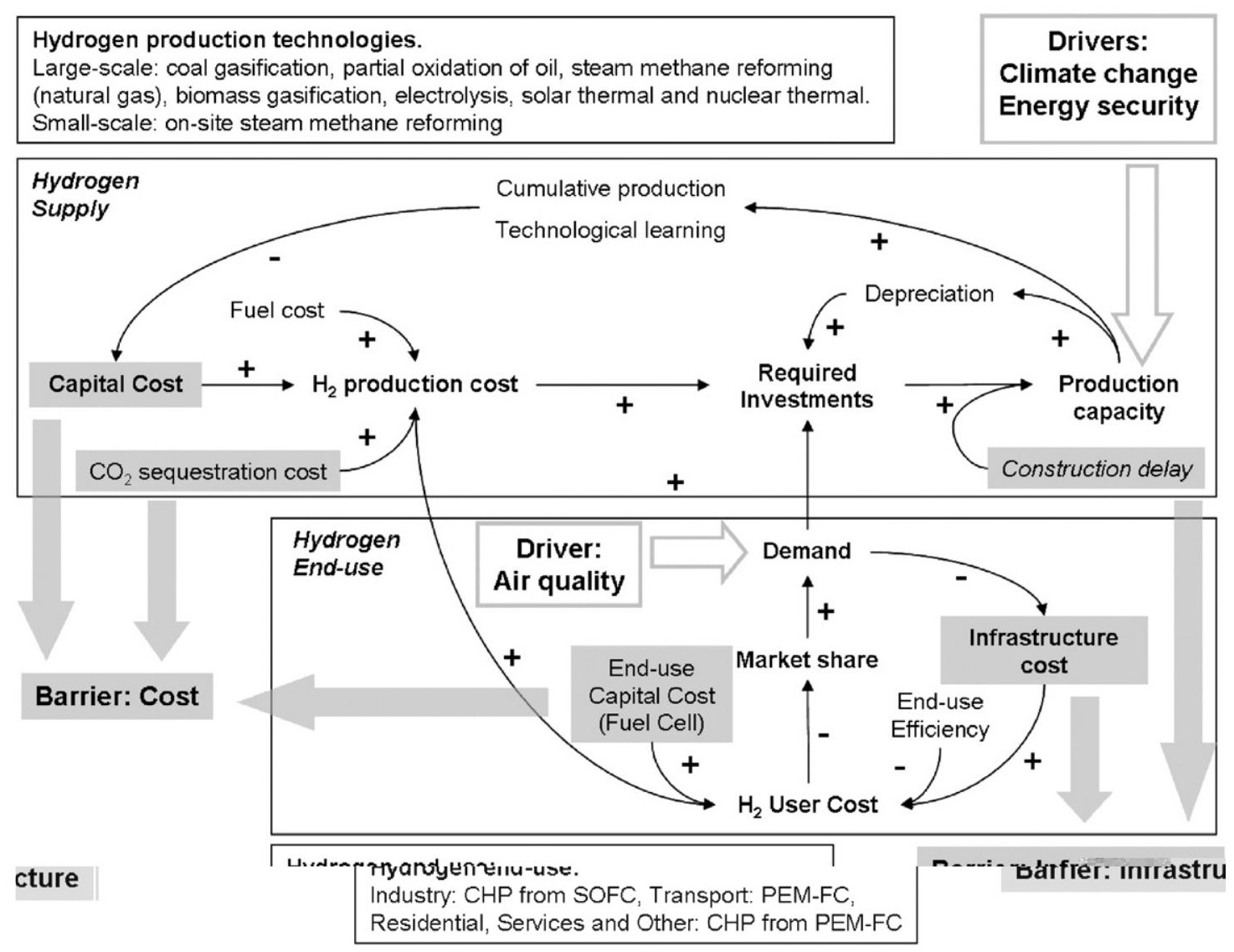

Fig. 4. Overview of the TIMER-hydrogen model, the relation with drivers and barriers is highlighted by large arrows. Small arrows indicate influence factors or inputs for calculation.

the system enters a second phase, in which pipeline transport becomes cost effective and large-scale production technologies become available for stationary end-use applications as well.

An important assumption in the model is that end-use of hydrogen only takes place in fuel cells. For stationary applications, these fuel cells produce both heat and power (CHP); in transport applications, the electricity is used to drive vehicles. This is not in line with the current research focus on internal combustion engines (ICEs), like the extended HyFLEET-CUTE project in Europe and research to three-wheelers and cookers in India. However, fuel cells have higher conversion efficiencies than ICEs, and thus use less hydrogen per unit of delivered useful energy (or energy service). Because hydrogen is relatively expensive, especially in the early phase of the transition, this leads to an economic advantage for fuel cells at the level of useful energy, despite their higher capital costs. Therefore, we assumed fuel cells to be the main hydrogen end-use technology. This influences the results on air pollution: direct combustion of hydrogen leads to higher $\mathrm{NO}_{x}$ emissions than other fuels because of the higher flame temperatures.

Because most Indian studies on hydrogen assume the use of international technology (Balachandra and Reddy, 2007; Bist, 2006), we use similar (global) assumptions on hydrogen technology for Western-Europe and India. The most important assumptions can be found in van Ruijven et al. (2007) and in the appendix. ${ }^{9} \mathrm{We}$ added one technology option for the production of hydrogen to the existing model: nuclear thermal hydrogen production. This is a potential option for future hydrogen production in India (Bist, 2006). In contrast to fossil energy-based technologies like coal gasification and SMR, it is only operational at the laboratory scale and it needs time and effort to become available at industrial scale (Crosbie and Chapin, 2003). According to the nuclear industry, the next generation of (uranium-based) nuclear reactors could be used to heat a sulphur-iodine (S-I) cycle to thermochemically produce hydrogen from water. We based our assumptions for nuclear thermal hydrogen production on publications of a General Atomics project that used the S-I cycle (Schultz et al., 2003), but this option represents the broader technology-field of nuclear hydrogen production. $^{10}$

\footnotetext{
${ }^{9} \mathrm{We}$ assumed similar progress ratios for all technologies, because in this stage we do not have reasons for diversification.

${ }^{10}$ In the model, nuclear thermal hydrogen production technology is available from the beginning of the century. However, it is hardly applied, due to limitations to large-scale technologies during the transition.
} 


\subsection{The TIMER- $\mathrm{H}_{2}$ scenarios}

In this study, we use the TIMER OECD-EO energy scenario (see Section 2.1) as baseline scenario and vary only assumptions on hydrogen energy technology development. We use a set of pessimistic, intermediate and optimistic assumptions for hydrogen energy technology development, based on literature estimates of cost and technology development - similar to our earlier global analysis (van Ruijven et al., 2007). The assumptions differ in terms of technology learning rates, but also on costs of infrastructure development and energy taxation. With respect to the latter, in the optimistic scenario we assume no energy taxation of hydrogen. We only vary assumptions on hydrogen technology itself; developments in other technologies (e.g. batteries, hybrid-vehicles) are assumed to be the same in all scenarios. We assume technological improvements to be exogenous and do not take into account any related costs, for instance R\&D investments. Below, the hydrogen scenarios are quantitatively described; the quantitative assumptions are provided in the appendix (Tables A1-A6).

- In the pessimistic set of hydrogen assumptions $\left(\mathrm{H}_{2}\right.$ PES), we describe a world in which no major hydrogenrelated breakthroughs are established and transitional dilemmas, like the chicken-egg problem with demand, supply and infrastructure development, are not solved. Technologies and costs continue to improve slowly between now and 2100 towards the lower range of technology parameters found in literature. ${ }^{11}$

- In the intermediate hydrogen scenario $\left(\mathrm{H}_{2} \mathrm{MED}\right)$, some promising improvements in technology are made, but after a while new boundaries are met. In particular in the first decades to come, fuel cells rapidly become cheaper. However, after this initial breakthrough, further progress slows down in the second half of the century. In the production phase, no major new cost reductions are achieved and, partly because the major development of fuel cell markets does not occur, production capacity stagnates and learning experience in hydrogen production technology is less than was hoped for. Some hydrogen distribution infrastructure is developed for the transport sector, but apart from a few niche markets the transition is costly. In this scenario, technologies improve to the lower range of technology estimates by 2050 .

- The third scenario describes the most optimistic case for hydrogen $\left(\mathrm{H}_{2} \mathrm{OPT}\right)$. In this scenario, breakthroughs in hydrogen technology are realised and transitional issues are vigorously solved. A major policy measure is that hydrogen is excluded from the taxation of energy, in order to stimulate its application. With respect to technology development, fuel cells are mass-produced

\footnotetext{
${ }^{11}$ Although the storylines of the scenarios involve the whole 21 st century, we limit our analysis to the period to 2050 .
}

at low cost, hydrogen production technology becomes cheaper and better through learning and distribution infrastructure is developed rapidly at low costs. In this scenario, technologies are assumed to improve rapidly to reach an intermediate range by 2030 and the most optimistic values in literature by 2100 .

\section{Scenarios for hydrogen energy in India and Western Europe}

In the TIMER OECD-EO scenario, the baseline scenario for the hydrogen analysis, the economic and demographic projections are medium compared to other studies (see Section 2). For India, GDP per capita is projected to increase from $460 \mathrm{USD}_{1995} / \mathrm{yr}$ in 2000 to 5000 $\mathrm{USD}_{1995} / \mathrm{yr}$ in 2050 , with a population increasing to almost 1.6 billion people. For Europe, GDP per capita is assumed to increase from $27,000 \mathrm{USD}_{1995} / \mathrm{yr}$ in 2000 to 63,000 $\mathrm{USD}_{1995} / \mathrm{yr}$ in 2050 , with slow population growth towards 400 million persons. Total primary energy use increases in both regions towards a level of about $70 \mathrm{EJ} / \mathrm{yr}$ (Fig. 1) and $\mathrm{CO}_{2}$ emissions reach $1.2 \mathrm{GtC} / \mathrm{yr}$ in both India and Western Europe. Below, we present the results of the hydrogen scenarios. It turns out that hydrogen is only applied in these regions before 2050 under intermediate and optimistic assumptions. Therefore, we exclude the pessimistic hydrogen scenario from further discussion.

An important note is that the global energy model TIMER model includes all world regions in parallel and that the assumptions on hydrogen and, for instance, climate policy also count for other world regions. Issues like trade and learning spill over are computed for the whole world and cannot be attributed to these two regions only. So, we focus on the regions of Western Europe and India, keeping in mind that the rest of the world is still involved.

\subsection{Hydrogen production}

Assuming that competition among the different technologies to produce hydrogen is mainly based on production costs, the results for the optimistic hydrogen scenario show that coal is clearly the cheapest option in both India and Western Europe, although initially natural gas is also attractive (Table 4). In both regions, technological learning makes biomass more attractive in the long run, followed by nuclear thermal hydrogen production. The share of fuel costs in the total production costs of hydrogen tends to increase for all technologies; learning-by-doing decreases capital cost, while at the same time depletion of resources increases fuel costs.

In line with these production costs, coal is the major production technology for hydrogen in India in the optimistic scenario, followed by small-scale and large-scale natural gas (Fig. 5). In the intermediate scenario, hydrogen remains too costly and it plays no role in the Indian energy system. Hydrogen production in Europe is also mainly 
Table 4

Hydrogen production cost (in $\$_{1995} / \mathrm{GJ}$ ) and percentage fuel cost (\%) for the optimistic scenario

\begin{tabular}{|c|c|c|c|}
\hline & 2010 & 2030 & 2050 \\
\hline \multicolumn{4}{|l|}{ India } \\
\hline Coal & $8.0(21 \%)$ & $7.5(24 \%)$ & $5.1(39 \%)$ \\
\hline Oil & $13.5(72 \%)$ & $13.4(73 \%)$ & $14.3(77 \%)$ \\
\hline Natural gas & $10.2(78 \%)$ & $8.9(78 \%)$ & $7.6(83 \%)$ \\
\hline Biomass & $13.6(53 \%)$ & $12.7(51 \%)$ & $11.9(53 \%)$ \\
\hline Electricity & $18.2(82 \%)$ & $19.1(83 \%)$ & $19.3(83 \%)$ \\
\hline Solar thermal & $47.6(\mathrm{~N} / \mathrm{A})$ & $36.5(\mathrm{~N} / \mathrm{A})$ & $31.0(\mathrm{~N} / \mathrm{A})$ \\
\hline Nuclear thermal & $12.3(4 \%)$ & $11.8(5 \%)$ & $11.8(6 \%)$ \\
\hline Small SMR & $25.2(30 \%)$ & $19.6(35 \%)$ & $14.2(44 \%)$ \\
\hline \multicolumn{4}{|l|}{ Western Europe } \\
\hline Coal & $9.5(34 \%)$ & $8.6(36 \%)$ & $6.1(50 \%)$ \\
\hline Oil & $14.1(73 \%)$ & $13.4(73 \%)$ & $14.0(76 \%)$ \\
\hline Natural gas & $9.6(77 \%)$ & $8.5(77 \%)$ & $8.2(85 \%)$ \\
\hline Biomass & $14.5(56 \%)$ & $14.2(56 \%)$ & $12.5(56 \%)$ \\
\hline Electricity & $28.9(89 \%)$ & $27.2(88 \%)$ & $24.2(87 \%)$ \\
\hline Solar thermal & $49.9(\mathrm{~N} / \mathrm{A})$ & $38.4(\mathrm{~N} / \mathrm{A})$ & $32.5(\mathrm{~N} / \mathrm{A})$ \\
\hline Nuclear thermal & $12.3(4 \%)$ & $11.9(5 \%)$ & $11.8(6 \%)$ \\
\hline Small SMR & $25.3(30 \%)$ & $19.4(35 \%)$ & $14.7(47 \%)$ \\
\hline
\end{tabular}

Hydrogen production costs are a combination of fuel cost (shown here between brackets), O\&M and (annualised) capital cost. based on coal gasification and steam reforming of natural gas (Fig. 5). In Europe too, there is hardly any demand for hydrogen in the intermediate scenario, although in absolute terms European demand in 2050 is comparable to the Indian demand in the optimistic hydrogen scenario.

\subsection{Hydrogen end-use}

In which sectors may hydrogen be applied? In India, there is a demand for hydrogen only in the transport sector in the optimistic scenario (Fig. 5); from 2020 onwards, the share of hydrogen in the Indian transport sector increases to $40 \%$ in 2050 . The share of hydrogen in total final energy use in India increases to about $6 \%$ in 2050. With intermediate cost and technology assumptions, hydrogen cannot compete with other options and does not enter the Indian energy system.

In Western Europe, our results show that there might be a role for hydrogen in both stationary and mobile applications (Fig. 5). In the optimistic scenario, hydrogen demand starts after 2010 and increases rapidly towards $27 \%$ market share in 2050 , mostly in the transport sector.
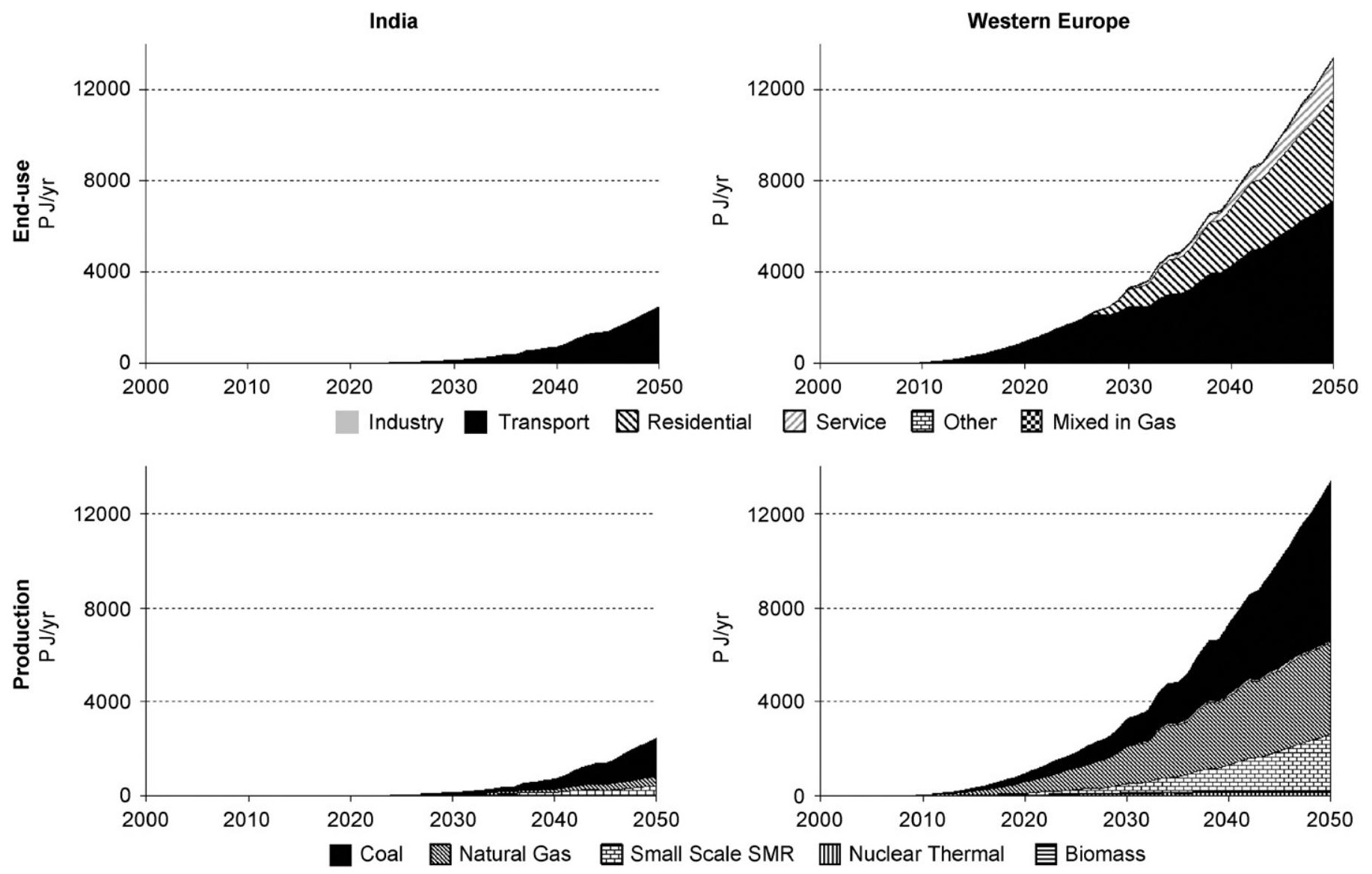

Fig. 5. End-use (upper graphs) and production (lower graphs) of hydrogen in India and Western Europe under optimistic scenario assumptions without climate policy. 


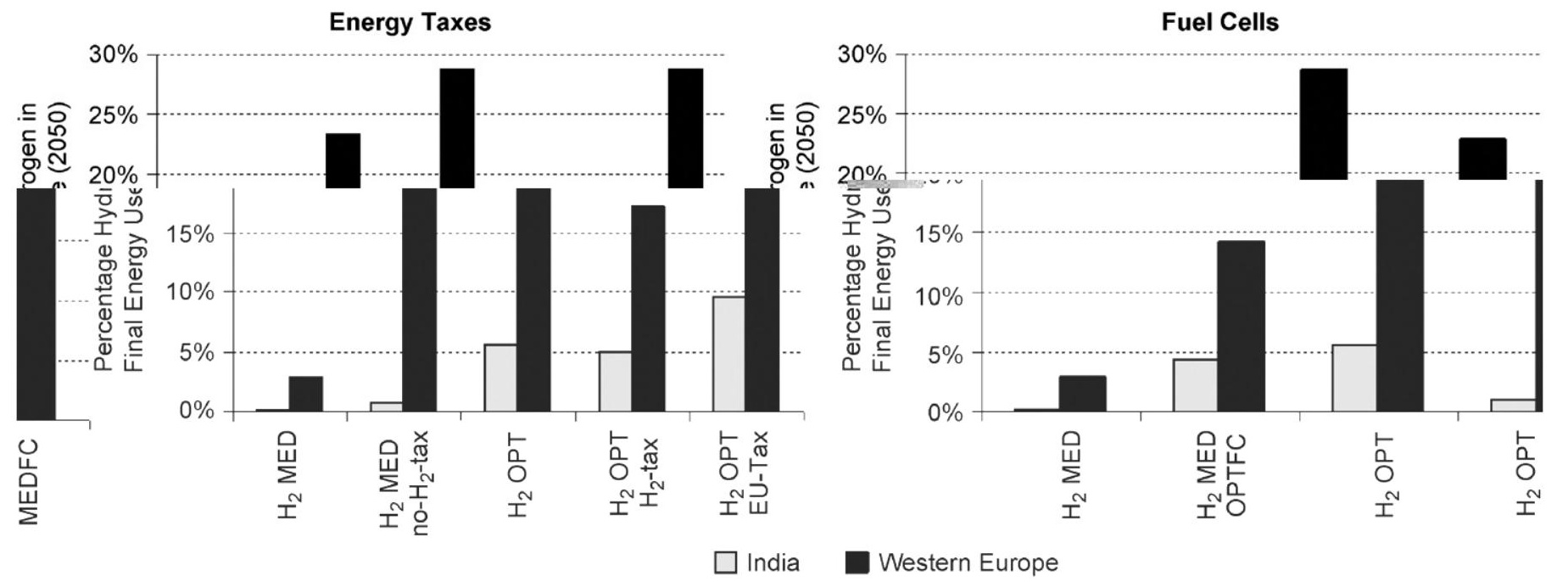

Fig. 6. Impact of energy taxes and fuel cell technology development on penetration levels of hydrogen in final energy use in 2050 in India and Western Europe.

With increasing hydrogen use in the transport sector, the development of pipeline infrastructure becomes more attractive. Around 2030, the threshold-hydrogen-use for infrastructure development is reached and large-scale produced, pipeline delivered hydrogen becomes available for stationary applications. This causes a rapid introduction of hydrogen in the Western European residential sector: the market share of hydrogen increases to about $40 \%$ in 2050 . Hydrogen use in the service sector increases more slowly towards $13 \%$ market share by 2050. In the intermediate scenario hydrogen only penetrates in the transport sector after 2040 and reaches about $10 \%$ market share by 2050 . Mixing hydrogen into the natural gas grid shows up in all scenarios in both regions, but represents only a minor share of the demand for hydrogen.

The end-use of hydrogen can also be expressed in terms of installed fuel cell capacity for power generation, a number that is also provided in the PRIMES scenario study for Europe, discussed in Section 2.3 (Mantzos et al., 2004). This study projects $56-58 \mathrm{GW}_{\mathrm{e}}$ of fuel cells in 2030 in scenarios with a policy focus on energy efficiency and renewable energy for the EU25. The TIMER optimistic scenario involves a similar capacity of $50 \mathrm{GW}_{\mathrm{e}}$ fuel cells in 2030 in Western Europe, ${ }^{12}$ increasing to $360 \mathrm{GW}_{\mathrm{e}}$ in 2050. The energy scenarios for India do not provide comparable quantitative indicators on hydrogen.

\subsubsection{Energy taxes}

One on the main explanations of the difference in hydrogen penetration between India and Western Europe is the level of energy taxes. The optimistic scenario assumes that hydrogen will not be taxed; a policy measure that also

\footnotetext{
${ }^{12}$ The PRIMES EU25 region includes the IMAGE/TIMER Western Europe and Eastern Europe regions. In the IMAGE/TIMER Eastern Europe region, no stationary fuel cell capacity is projected until 2050.
}

plays a role in current European policies to stimulate biofuels (Bomb et al., 2007). ${ }^{13}$

Historically, the Western Europe has the highest energy taxes of the world, which results in a favourable position of hydrogen compared to other fuels (mainly oil and natural gas) if it is exempted from energy taxes. The results of two variants of the existing scenarios, i.e. a $\mathrm{H}_{2}$ MED scenario with tax exemption for hydrogen and $\mathrm{H}_{2}$ OPT with hydrogen taxed, show that the tax exemption explains most of the difference between the intermediate and optimistic scenarios for Europe, while it hardly makes a difference in India (Fig. 6, left graph). Most likely, energy taxes in developing countries will increase: investments in transport and energy infrastructure need to be financed and higher energy taxes are one of the options to generate the required finances (de Vries et al., 2007; van Vuuren et al., 2003). In recent years, energy taxes for the transport sector in India increased, although prices are still about $40 \%$ lower than in Europe (IEA, 2007; Metschies, 2005). Therefore, we also include a case in which India really adopts the Western European energy taxes by 2025 for all fuels other than hydrogen. This shows the impact of the tax exemption measure, as hydrogen penetration reaches $10 \%$, almost twice the percentage of the optimistic scenario. ${ }^{14}$

\subsubsection{Fuel cell development}

Another key uncertainty in the development of hydrogen energy systems is technology development. With respect to hydrogen demand, the development of costs and efficiency of fuel cells is one of the main factors ${ }^{15}$ for which future

\footnotetext{
${ }^{13} \mathrm{On}$ the long-term, this assumption might be unrealistic for a fuel that becomes dominant in several sectors, but we aimed to describe the most optimistic case for hydrogen energy.

${ }^{14}$ For Europe, this scenario is equal to $\mathrm{H}_{2} \mathrm{OPT}$.

${ }^{15}$ Other factors include, for instance, the costs and structure of infrastructure, hydrogen production technology development and the availability and development of CCS technology.
} 
estimates in literature vary widely. The scenario assumptions are based on the range in literature (see Table A6), and to isolate the impact of fuel cell development, we analyse a variant of the intermediate scenario that includes optimistic assumptions on fuel cells and vice versa (Fig. 6, right graph). In India, the difference between the intermediate and optimistic scenarios can largely be explained from differences in fuel cell development; it has much more impact than assumptions on energy tax. For Europe, the impact of fuel cell development is of less importance for hydrogen penetration than energy taxation policy. With less fuel cell development there is no European demand for hydrogen from stationary applications, because heat supply from natural gas and oil is more attractive.

\section{Driving forces of hydrogen: climate policy, energy security and urban air quality}

\subsection{Climate policy}

What could be the role of hydrogen if the worldincluding Europe and India-would formulate and implement a stringent climate policy? Let us assume, for the purpose of clarity, that an ambitious target of stabilisation at 450 ppmv $\mathrm{CO}_{2}$-eq. is agreed upon by the world community. This would allow global carbon emissions to increase to about $9 \mathrm{GtC} / \mathrm{yr}$ in 2015 after which they have to decrease to $4 \mathrm{GtC} / \mathrm{yr}$ in 2050 (den Elzen and Lucas, 2003; van Vuuren et al., 2007). Using a cost-optimal allocation scheme with the assumption of global trade in emissions, we can simulate a scenario with such a carbon constraint by introducing a global carbon tax path and examine the reduction of emissions that takes place in each region. For the TIMER OECD-EO baseline scenario (without $\mathrm{H}_{2}$ ) this would imply a linearly increasing carbon tax to a level of $700 \$ / \mathrm{tC}$, leading to a carbon emission reduction (compared to the baseline) for India and Europe of, respectively, $70 \%$ and $60 \%$ by the year 2050 .

How does such a carbon tax change the energy system and which role does hydrogen play? One would expect in the first instance a higher market penetration for hydrogen, as it is a carbon-free fuel. Of course, this may be incorrect: the most preferred route to make hydrogen is from coal, which involves carbon emissions up to $45 \%$ higher than using gasoline or diesel from oil. Only if non-carbon options such as renewable or nuclear energy become competitive - which happens earlier because coal is taxed - the hydrogen route will result in lower carbon emissions. Or, alternatively, if CCS is available at costs, which keep the coal-to-hydrogen route still (the most) competitive one. Whatever the result, the hydrogen option tends to increase the adaptability of the energy system in case of climate policy.

If we look into the total carbon emissions of the energy system, our simulation results indicate that in India a stringent climate policy will generate drastic changes in the energy system (Fig. 7, upper left). However, whether the hydrogen option is available does not make a difference (Fig. 7, lower left). This is because hydrogen plays a minor role in the Indian energy system - only $6 \%$ of the final energy use in 2050 in the optimistic scenario. It is not competitive
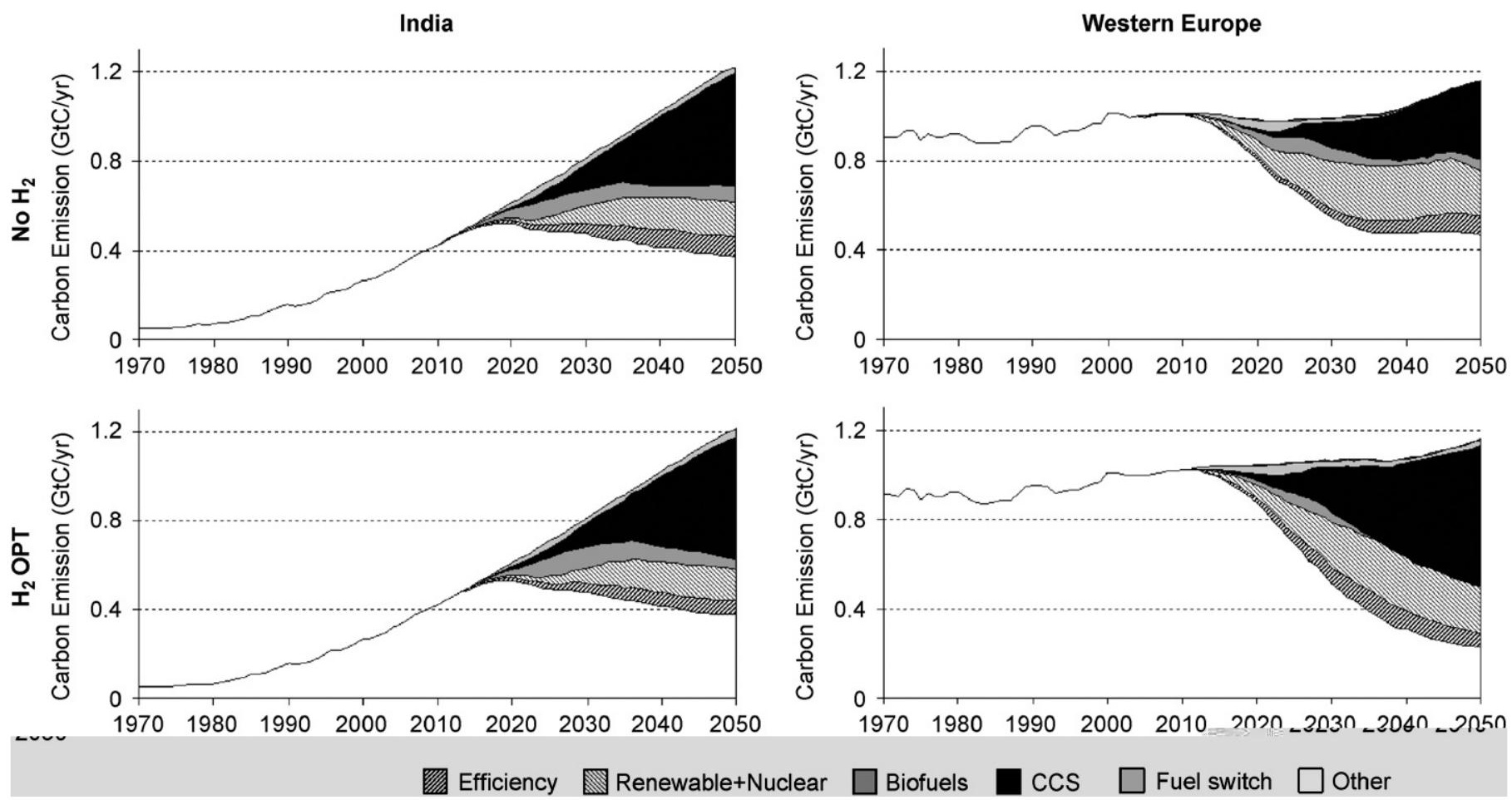

Fig. 7. Carbon emission reduction measures needed to reach the $450 \mathrm{ppmv}$ stabilisation path for India and Western Europe in scenarios without hydrogen and in the $\mathrm{H}_{2}$ OPT scenario. 
with other carbon emission reduction options such as coalwith-CCS for electricity production and biofuels.

For Europe, a stringent climate policy will reduce carbon emissions and hydrogen may make a significant difference (Fig. 7, upper right and lower right). Without the hydrogen option, carbon emissions in Western Europe stabilise at about $0.5 \mathrm{GtC} / \mathrm{yr}$ after 2030. With optimistic hydrogen assumptions, carbon emissions decrease to about $0.3 \mathrm{GtC} / \mathrm{yr}$ in 2050 with a global carbon tax rising to only $350 \$ / \mathrm{tC}$. This is mainly the result of large-scale implementation of the coal-to-hydrogen-with-CCS route (Fig. 7, lower right). Other options, such as renewable and nuclear energy, follow a slightly different path - the prospects for biomassbased transport fuels are negatively affected by the availability of a cheap clean-coal-based hydrogen route.

The key difference between India and Europe is that hydrogen is penetrating the energy system at an earlier date in Europe, which implies that most transition barrierssuch as high costs and infrastructure development - have assumedly disappeared. This results in a more competitive position in three sectors and thus a larger potential for further penetration as a consequence of climate policy in Europe than in India. Interestingly, the prospects for hydrogen from nuclear energy do not differ in relative sense. With stringent climate policy, both regions may produce about $10-15 \%$ of their hydrogen via the nuclear thermal route in 2050 in both the intermediate and optimistic scenarios. This amounts to $8 \mathrm{GW}-\mathrm{H}_{2}$ in India and $100 \mathrm{GW}-\mathrm{H}_{2}$ in European installed capacity by 2050 . Nuclear energy becomes competitive as the result of cost increases in fossil fuel due to carbon tax and CCS.

Our simulation results suggest that a stringent climate policy does not accelerate the penetration of hydrogen into the Indian energy system. Evidently, the boost for hydrogen in Western Europe will also affect the potential for hydrogen in other energy markets as learning in hydrogen production technologies spills over to other regions. However, production costs are only a minor part in the cost of hydrogen for end-users (see Table 4); the above-described impact of energy taxation is more decisive and prevents an increased role for hydrogen in India.

\subsection{Energy security}

Another question: will hydrogen decrease the anticipated tensions on the world oil and gas market? To investigate this issue, we compare the fuel trade patterns in Western Europe and India for the scenarios with and without hydrogen $\left(\mathrm{H}_{2}\right.$ PES and $\mathrm{H}_{2}$ OPT, see Fig. 8). One would, again, expect a beneficial effect of competitive hydrogen technology because of its substitution effect in the car fuel market. However, here too, the net effect on fuel trade will depend on how the hydrogen is produced. The simulation results indicate (Fig. 8) that for optimistic assumptions on hydrogen costs and technology:

- In India, where almost all oil has to be imported (Section 3.1.2), secondary fuel demand for oil in the transport sector will grow much slower and even decline around 2040.

- In Europe, the effect is a temporarily higher oil import than in the baseline, because hydrogen slows down the penetration of biofuels in the transport sector; relative imports of oil also decrease in Europe, from $60 \%$ in 2050 without hydrogen to $40 \%$ with optimistic hydrogen assumptions.

- Because the coal-to-hydrogen route is the most competitive one, with gas-to-hydrogen a good second one, in the longer term coal and gas imports increase in Europe; in India, with its large indigenous coal resources, the net change for coal trade is nearly zero.

The simulation results warrant the conclusion that the availability of competitive hydrogen technology will alleviate most probably the future tensions on the world oil market, largely through fuel diversification towards coal and natural gas. For emerging regions like India, this can mitigate balance-of-payment problems, because imported oil can be substituted by indigenously available coal.

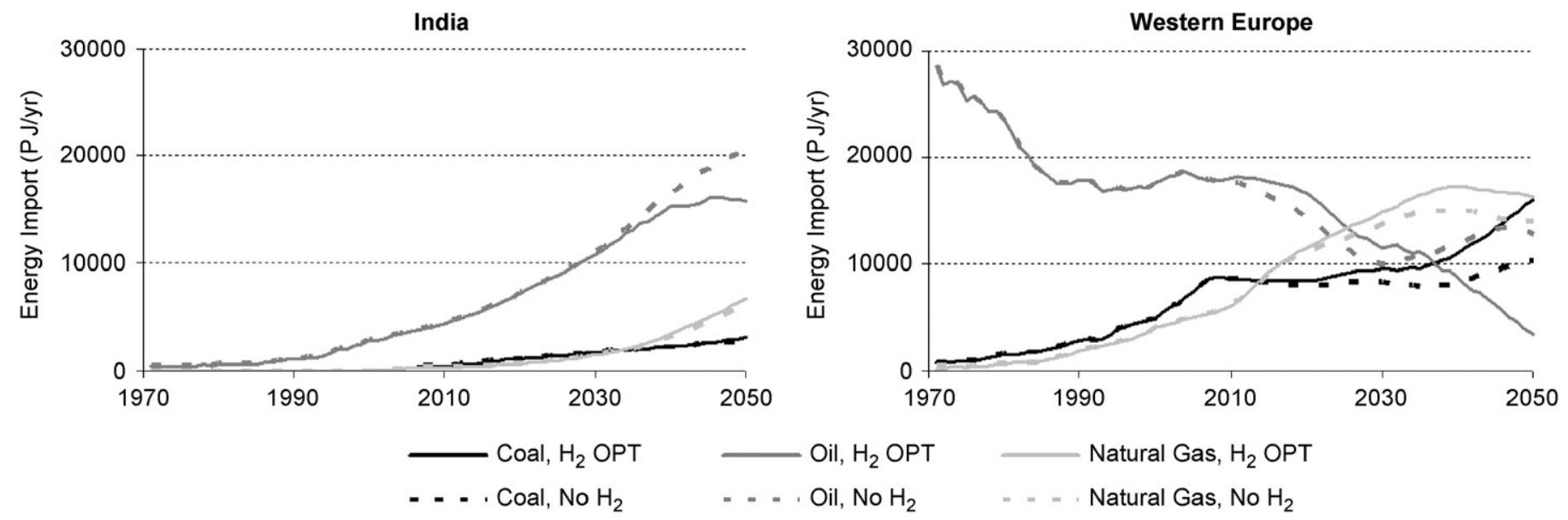

Fig. 8. Projections for import of fossil energy in India and Western Europe in scenarios with pessimistic (baseline) and optimistic assumptions on hydrogen energy. 


\subsection{Urban air quality}

A last question to be addressed in this comparison between the prospects of hydrogen for India and Western Europe has to do with air pollution: Will hydrogen contribute in a cost-effective way to urban air pollution abatement and what is the role of more stringent environmental policies. This issue is probably the hardest one to answer. Most high-income regions have rather stringent policies for important urban pollutants like $\mathrm{NO}_{x}, \mathrm{SO}_{2}$ and particulate matter. In low-income regions, environmental policies generally less stringent and future developments are uncertain - although the hypothesis of an Environmental Kuznets Curve suggests more stringent norms with rising income (for discussion, see e.g. Stern, 2004). Whatever the region: the more stringent and effective environmental policies are, the less difference will hydrogen use make in urban areas, under the assumption that the fuel cell is the dominant end-use technology (see Tables 5 and 6). In this context, the recent shift of three-wheelers and buses towards CNG (see also Section 3.1.3) in many Indian cities indicates two issues. On the one hand, it shows that Indian cities are capable to force a transition towards a different fuel; on the other hand, the resulting air quality improvement decreases the potential benefits of hydrogen. However, there is a second element: How clean will hydrogen production be and how much does it matter where it takes place? If emission standards are low (i.e. India), the net pollution effect may be negative, as emissions at end-use in transport decrease but emissions from hydrogen production increase. This, as with climate and security effects, will depend to a significant degree upon the preferred hydrogen production route and its cost and technology characteristics.

Table 5

Annual $\mathrm{SO}_{2}$ emissions $\left(\mathrm{Tg} \mathrm{SO}_{2}\right)$ from transport, power and hydrogen production and total energy use for scenarios without hydrogen and with optimistic hydrogen assumptions, and with stringent Air Pollution Policy (APP)

\begin{tabular}{|c|c|c|c|c|}
\hline & \multicolumn{2}{|l|}{ India } & \multicolumn{2}{|c|}{ Western Europe } \\
\hline & 2000 & 2050 & 2000 & 2050 \\
\hline \multicolumn{5}{|l|}{ Transport } \\
\hline Baseline-no $\mathrm{H}_{2}$ & 0.34 & 0.27 & 0.30 & 0.17 \\
\hline $\mathrm{H}_{2} \mathrm{OPT}$ & & 0.11 & & 0.05 \\
\hline $\mathrm{APP}-\mathrm{no} \mathrm{H}_{2}$ & & 0.04 & & 0.02 \\
\hline $\mathrm{APP}-\mathrm{H}_{2} \mathrm{OPT}$ & & 0.02 & & 0.01 \\
\hline \multicolumn{5}{|c|}{ Power and $\mathrm{H}_{2}$ production } \\
\hline Baseline - no $\mathrm{H}_{2}$ & 1.38 & 5.98 & 1.55 & 0.35 \\
\hline $\mathrm{H}_{2} \mathrm{OPT}$ & & 6.01 & & 0.29 \\
\hline $\mathrm{APP}-\mathrm{no} \mathrm{H}_{2}$ & & 0.18 & & 0.25 \\
\hline $\mathrm{APP}-\mathrm{H}_{2} \mathrm{OPT}$ & & 0.18 & & 0.21 \\
\hline \multicolumn{5}{|l|}{ Total } \\
\hline Baseline - no $\mathrm{H}_{2}$ & 3.45 & 11.09 & 4.45 & 2.02 \\
\hline $\mathrm{H}_{2} \mathrm{OPT}$ & & 10.80 & & 1.77 \\
\hline $\mathrm{APP}-\mathrm{no} \mathrm{H}_{2}$ & & 0.79 & & 0.49 \\
\hline $\mathrm{APP}-\mathrm{H}_{2} \mathrm{OPT}$ & & 0.77 & & 0.43 \\
\hline
\end{tabular}

Table 6

Annual $\mathrm{NO}_{x}$ emissions $\left(\mathrm{Tg} \mathrm{NO}_{x}\right.$ ) from transport, power and hydrogen production and total energy use for scenarios without hydrogen and with optimistic hydrogen assumptions, and with stringent Air Pollution Policy (APP)

\begin{tabular}{|c|c|c|c|c|}
\hline & \multicolumn{2}{|l|}{ India } & \multicolumn{2}{|c|}{ Western Europe } \\
\hline & 2000 & 2050 & 2000 & 2050 \\
\hline \multicolumn{5}{|l|}{ Transport } \\
\hline Baseline - no $\mathrm{H}_{2}$ & 0.32 & 0.37 & 1.88 & 0.58 \\
\hline $\mathrm{H}_{2} \mathrm{OPT}$ & & 0.15 & & 0.16 \\
\hline $\mathrm{APP}-\mathrm{no} \mathrm{H}_{2}$ & & 0.08 & & 0.43 \\
\hline $\mathrm{APP}-\mathrm{H}_{2} \mathrm{OPT}$ & & 0.03 & & 0.12 \\
\hline \multicolumn{5}{|c|}{ Power and $\mathrm{H}_{2}$ production } \\
\hline Baseline - no $\mathrm{H}_{2}$ & 0.59 & 2.87 & 0.56 & 0.39 \\
\hline $\mathrm{H}_{2} \mathrm{OPT}$ & & 3.27 & & 0.57 \\
\hline $\mathrm{APP}-\mathrm{no} \mathrm{H}_{2}$ & & 0.23 & & 0.17 \\
\hline $\mathrm{APP}-\mathrm{H}_{2} \mathrm{OPT}$ & & 0.26 & & 0.27 \\
\hline \multicolumn{5}{|l|}{ Total } \\
\hline Baseline - no $\mathrm{H}_{2}$ & 1.58 & 4.41 & 3.02 & 1.57 \\
\hline $\mathrm{H}_{2} \mathrm{OPT}$ & & 4.58 & & 1.22 \\
\hline $\mathrm{APP}-\mathrm{no} \mathrm{H}_{2}$ & & 0.71 & & 0.81 \\
\hline $\mathrm{APP}-\mathrm{H}_{2} \mathrm{OPT}$ & & 0.69 & & 0.57 \\
\hline
\end{tabular}

\section{Discussion and conclusion}

In this study, we used the TIMER global energy model to analyse the potential role of hydrogen in two different world regions, Western Europe and India, as representatives of high and low-income regions. The model permits an exploration of what might happen with the energy systems in these regions if hydrogen technologies are assumed to become available. In order to explore the ranges of possible future developments, we used three different scenarios on the development of costs and technology of hydrogen, based on ranges in literature. Some results are similar in all scenarios, and might be considered plausible impacts of hydrogen on the energy system. Other results are dependent on the specific scenario assumptions and should therefore be approached more carefully and interpreted in the scenario context. Our main findings are:

- Considerable cost reductions and technology development are needed for hydrogen energy technology, in order to play a major role in the energy systems of both India and Western Europe before 2050. Only in our most optimistic scenario hydrogen is deployed at a large scale.

- Two factors are crucial for the penetration of hydrogen in final energy use:

(a) Energy taxation policy; in many low-income regions energy, is hardly taxed or even subsidised. This restricts policy options to stimulate alternative fuels and limits the potential for hydrogen energy application.

(b) Fuel cell technology development; fuel cells are the key technology for the efficient application of 
hydrogen; the level of cost reductions that can be achieved is very much determining the success of hydrogen energy.

- The availability of a competitive hydrogen option in the energy system has several attractive trade-offs:

(a) Mitigation of carbon emissions can be cheaper; the coal-to-hydrogen route makes carbon capture and storage an available option for the transport sector.

(b) There is probably less pressure on the international oil market; as hydrogen substitutes oil in the transport sector, the international demand for oil can be significantly reduced.

(c) Possibly, urban air quality can be improved; this is contingent upon the specific locations of hydrogen application (mostly in urban centres) and production (mostly in less populated areas) and the autonomous policy process of improved emission standards (generally, lower standards in developing countries).

- Prospects for hydrogen are more limited in India than in Europe, mainly due to lower energy prices (and taxes). Therefore, the most direct advantage of hydrogen for India might be that the international oil market potentially relaxes, while at the same time the need for imports slightly decreases. The projections for India show that hydrogen does not play an important role for carbon mitigation and that air quality improvement depends strongly on the improvement of emission standards.

- The model results indicate a high potential for hydrogen in Western Europe. The overall advantage of hydrogen for Western Europe can be summarised as a higher domestic carbon reduction potential at lower cost, decreased oil imports and an attractive option to improve air quality.

\section{Acknowledgements}

The authors wish to thank Jeroen van der Sluijs (UU) and Prof. D.S. Hegde (NITIE) for their comments on earlier drafts of this article and Frank de Leeuw (MNP) for providing data from the AirBase air quality database. We also thank the Indira Ghandi Institute of Development Research (IGIDR) in Mumbai for using its facilities and Prof. B. Sudhakara Reddy for his suggestions on this project. This research is financially supported by the Netherlands Environmental Assessment Agency (MNP).

\section{Appendix. Key assumptions for the hydrogen scenarios}

See Tables A1-A6.

Table A1

Scenario assumptions on hydrogen production efficiency

\begin{tabular}{|c|c|c|c|c|c|c|c|c|}
\hline & $\begin{array}{l}\text { Coal gasification } \\
(\%)\end{array}$ & $\begin{array}{l}\text { Oil (POX) } \\
(\%)\end{array}$ & $\begin{array}{l}\text { Gas (SMR) } \\
(\%)\end{array}$ & $\begin{array}{l}\text { Biomass } \\
\text { gasification }(\%)\end{array}$ & Electrolysis (\%) & $\begin{array}{l}\text { Nuclear Th. } \\
\left(\mathrm{PJH}_{2} / \text { TonneU) }\right.\end{array}$ & $\begin{array}{l}\text { Solar } \\
\text { thermal }\end{array}$ & $\begin{array}{l}\text { Small-Scale } \\
\text { SMR }(\%)\end{array}$ \\
\hline $2005-2100$ & $\begin{array}{l}\text { Pessimistic } \\
60 \\
\text { Intermediate }\end{array}$ & 50 & 75 & 50 & 75 & 109 & $\mathrm{~N} / \mathrm{A}$ & 75 \\
\hline 2005 & 60 & 50 & 75 & 50 & 80 & 109 & $\mathrm{~N} / \mathrm{A}$ & 75 \\
\hline 2050 & 62.5 & 70 & 82 & 62.5 & 82 & 109 & $\mathrm{~N} / \mathrm{A}$ & 82 \\
\hline 2100 & $\begin{array}{l}65 \\
\text { Optimistic }\end{array}$ & 75 & 85 & 65 & 85 & 109 & $\mathrm{~N} / \mathrm{A}$ & 85 \\
\hline 2005 & 60 & 70 & 75 & 50 & 80 & 109 & $\mathrm{~N} / \mathrm{A}$ & 75 \\
\hline 2030 & 62.5 & 72.5 & 82.5 & 62.5 & 82 & 109 & $\mathrm{~N} / \mathrm{A}$ & 82 \\
\hline 2100 & 67.5 & 77.5 & 87.5 & 67.5 & 85 & 109 & $\mathrm{~N} / \mathrm{A}$ & 85 \\
\hline
\end{tabular}

Table A2

Scenario assumptions on initial hydrogen production investment costs $\left(\$_{1995} / \mathrm{kW}\right)$ and technological learning progress ratio

\begin{tabular}{|c|c|c|c|c|c|c|c|c|}
\hline Variable & $\begin{array}{l}\text { Coal } \\
\text { gasification }\end{array}$ & $\begin{array}{l}\text { Oil } \\
\text { (POX) }\end{array}$ & $\begin{array}{l}\text { Gas } \\
\text { (SMR) }\end{array}$ & $\begin{array}{l}\text { Biomass } \\
\text { gasification }\end{array}$ & Electrolysis & $\begin{array}{l}\text { Nuclear } \\
\text { thermal }\end{array}$ & $\begin{array}{l}\text { Solar } \\
\text { thermal }\end{array}$ & $\begin{array}{l}\text { Small-scale } \\
\text { SMR }\end{array}$ \\
\hline & Pessimistic & & & & & & & \\
\hline Init. inv. cost $(\$ / \mathrm{kW})$ & 1150 & 700 & 400 & 1150 & 575 & 1312 & 2875 & 3000 \\
\hline \multirow[t]{2}{*}{ Progress ratio } & 0.88 & 0.88 & 0.88 & 0.88 & 0.88 & 0.88 & 0.88 & 0.88 \\
\hline & Intermediate & & & & & & & \\
\hline Init. inv. cost $(\$ / k W)$ & 1000 & 600 & 350 & 1000 & 500 & 1312 & 2500 & 3000 \\
\hline \multirow[t]{2}{*}{ Progress ratio } & 0.84 & 0.84 & 0.84 & 0.84 & 0.84 & 0.84 & 0.84 & 0.84 \\
\hline & Optimistic & & & & & & & \\
\hline Init. inv. cost $(\$ / \mathrm{kW})$ & 900 & 550 & 300 & 900 & 450 & 1312 & 2250 & 2700 \\
\hline Progress ratio & 0.785 & 0.785 & 0.785 & 0.785 & 0.785 & 0.785 & 0.785 & 0.785 \\
\hline
\end{tabular}


Table A3

Assumptions on carbon capture and sequestration

\begin{tabular}{llll}
\hline Technology & $\begin{array}{l}\text { Capital cost } \\
\left(\$_{1995} / \mathrm{kW}\right)\end{array}$ & $\begin{array}{l}\text { Efficiency } \\
\text { loss }(\%)\end{array}$ & $\begin{array}{l}\mathrm{CO}_{2} \text { capture } \\
(\%)\end{array}$ \\
\hline Coal (gasification) & 197 & 3 & 95 \\
Oil (POX) & 185 & 2 & 95 \\
Natural gas (SMR) & 76 & 2 & 88 \\
\hline
\end{tabular}

Table A4

Scenario assumptions for hydrogen transport cost $\left(\$_{1995} / \mathrm{GJ}\right.$, as function of hydrogen use per capita)

\begin{tabular}{cccc}
\hline Hydrogen demand & Pessimistic & Intermediate & Optimistic \\
\hline 0 (GJ/capita) & 12 & 10 & 10 \\
20 (GJ/capita) & 10 & 6.5 & 5 \\
50 (GJ/capita) & 8 & 5 & 2 \\
70 (GJ/capita) & 6 & 3 & 2 \\
100 (GJ/capita) & 6 & 3 & 2 \\
\hline
\end{tabular}

Table A5

Scenario assumptions for local hydrogen distribution cost and refuelling $\left(\$_{1995} / \mathrm{GJ}\right)$

\begin{tabular}{|c|c|c|c|c|c|}
\hline$t$ & Industry & Transport & Residential & Services & Other \\
\hline & \multicolumn{5}{|c|}{ Pessimistic } \\
\hline 2005 & 2 & 6 & 3 & 2 & 3 \\
\hline \multirow[t]{2}{*}{2100} & 1 & 4 & 2 & 1 & 3 \\
\hline & \multicolumn{5}{|c|}{ Intermediate } \\
\hline 2005 & 2 & 5 & 3 & 2 & 3 \\
\hline 2050 & 1 & 3 & 2 & 1 & 3 \\
\hline \multirow[t]{2}{*}{2100} & 0.75 & 2 & 1.5 & 0.75 & 3 \\
\hline & \multicolumn{5}{|l|}{ Optimistic } \\
\hline 2005 & 1 & 4.5 & 2 & 1 & 3 \\
\hline 2030 & 0.75 & 3 & 1.5 & 0.75 & 3 \\
\hline 2100 & 0.50 & 1 & 1 & 0.50 & 3 \\
\hline
\end{tabular}

\section{Table A6}

Scenario assumptions on fuel cell investment cost $\left(\$_{1995} / \mathrm{kW}\right)$ and end-use efficiency in the transport sector

\begin{tabular}{|c|c|c|c|c|c|c|}
\hline$t$ & Industry & Residential & Service & Other & Transport & $\begin{array}{l}\mathrm{FC} \eta \\
\text { transport } \\
\text { sector }(\%)\end{array}$ \\
\hline & \multicolumn{6}{|c|}{ Pessimistic } \\
\hline 2005 & 1500 & 1400 & 1400 & 1500 & 1200 & 36 \\
\hline \multirow[t]{2}{*}{2100} & 800 & 500 & 500 & 800 & 250 & \\
\hline & \multicolumn{6}{|c|}{ Intermediate } \\
\hline 2005 & 1500 & 1400 & 1400 & 1500 & 1200 & 36 \\
\hline 2050 & 800 & 500 & 500 & 800 & 250 & 45 \\
\hline \multirow[t]{2}{*}{2100} & 500 & 300 & 300 & 500 & 200 & 45 \\
\hline & \multicolumn{6}{|c|}{ Optimistic } \\
\hline 2005 & 1350 & 1400 & 1400 & 1500 & 1200 & 40 \\
\hline 2030 & 100 & 100 & 100 & 100 & 100 & 50 \\
\hline 2100 & 50 & 50 & 50 & 100 & 50 & 60 \\
\hline
\end{tabular}

\section{References}

Balachandra, P., Reddy, B.S., 2007. Hydrogen Energy for the Transport Sector: A Well-To-Wheel Techno-Economic and Environmental Feasibility Analysis. IGIDR, Mumbai, p. 35.

Barreto, L., Makihira, A., Riahi, K., 2003. The hydrogen economy in the 21st century: a sustainable development scenario. International Journal of Hydrogen Energy 28, 267-284.

Bist, B.M.S., 2006. Hydrogen energy status in India and road map for 2020. Akshay Urja-Renewable Energy Newsletter 2, 19-24.

Bomb, C., McCormick, K., Deurwaarder, E., Kaberger, T., 2007. Biofuels for transport in Europe: Lessons from Germany and the UK. Energy Policy 35, 2256-2267.

Bouwman, A.F., Hartman, M.P.M., Klein Goldewijk, C.G.M. (Eds.), 2006. Integrated Modelling of Global Environmental Change. An overview of IMAGE 2.4. Netherlands Environmental Assessment Agency, Bilthoven, The Netherlands.

Campbell, C.J., 2002. Petroleum and people. Population and Environment 24, 193-207.

Central Pollution Control Board, 2004. website:〈www.cpcb.nic.in〉.

Chopra, S.K., 2006. Emerging renewable energy technologies in India. Akshay Urja-Renewable Energy Newsletter 2, 25-29.

Council of the European Union, 2007. Brussels European Council, 8/9 March 2007, Precidency Conclusions. Council of the European Union, Brussels.

Crosbie, L.M., Chapin, D., 2003. Hydrogen Production by Nuclear Heat. GENES4/ANP2003, Kyoto, Japan.

de Vries, H.J.M., van Vuuren, D.P., den Elzen, M.G.J., Janssen, M.A., 2001. The TIMER IMage Energy Regional (TIMER) Model. National Institute for Public Health and the Environment (RIVM), Bilthoven, p. 188.

de Vries, H.J.M., Revi, A., Bhat, G.K., Hilderink, H., Lucas, P.L., 2007. India 2050: Scenarios For An Uncertain Future. Netherlands Environmental Assessment Agency (MNP), Bilithoven.

den Elzen, M.G.J., Lucas, P., 2003. FAIR 2.0-A Decision-support Tool to Assess the Environmental and Economic Consequences of Future Climate Regimes. National Institute of Public Health and the Environment, Bilthoven, The Netherlands, p. 91.

den Elzen, M.G.J., Meinshausen, M., 2005. Meeting the EU $2{ }^{\circ} \mathrm{C}$ Climate Target: Global and Regional Emission Implications. Netherlands Environmental Assessment Agency (MNP), Bilthoven, p. 45.

Dhar, S., 2007. Future gas market scenarios for India: integrated energy and environment policies. In: Workshop on Climate Change Response Strategies: Perspectives in Modelling for Developing Economies. IIM, Ahmedabad.

Dunn, S., 2001. Hydrogen Futures: Toward a Sustainable Energy System. Worldwatch Institute, Washington.

Edmonds, J., Clarke, J., Dooley, J., Kim, S.H., Smith, S.J., 2004 Stabilization of $\mathrm{CO}_{2}$ in a $\mathrm{B} 2$ world: insights on the roles of carbon capture and disposal, hydrogen, and transportation technologies. Energy Economics 26, 517-537.

European Commission, 2003. Hydrogen Energy and Fuel Cells, a vision for our future. High Level Group for Hydrogen and Fuel Cells, Brussels, p. 16.

European Topic Centre on Air and Climate Change, 2005. AirBase-the European Air Quality dataBase. European Environment Agency.

Garg, A., Shukla, P.R., Ghosh, D., Kapshe, M., Rajesh, N., 2003. Future greenhouse gas and local pollutant emissions for India: policy links and disjoints. Mitigation and Adaptation Strategies for Global Change 8, 71-92.

Hendriks, C., Harmelink, M., Hofmans, Y., de Jager, D., 2002. Climate Neutral Energy Carriers in the Regulatory Energy Tax. Ecofys, Utrecht, p. 60.

Hendriks, C., Graus, W., van Bergen, F., 2004. Global Carbon Dioxide Storage Potential and Costs. Ecofys, Utrecht, p. 64.

Hoogwijk, M., 2004. On the Global and Regional Potential of Renewable Energy Sources. Science Technology and Society, Utrecht University, Utrecht, p. 256. 
IEA, 2004. World Energy Outlook 2004. International Energy Agency, Paris. IEA, 2006. World Energy Outlook 2006. International Energy Agency, Paris.

IEA, 2007. Energy Prices and Taxes. International Energy Agency, Paris, p. 520.

Kram, T., Bakkes, J., 2006. Analysis of environmental pressures and impacts of the baseline for the second OECD Environment Outlook. Netherlands Environmental Assessment Agency (MNP), Bilthoven, p. 89.

Lovins, A., 2003. Twenty Hydrogen Myths. Rocky Mountain Institute, Snowmass, p. 49

Mantzos, L., Capros, P., Zeka-Paschou, M., 2004. In: Chesshire, J., Guilmot, J.F. (Eds.), European Energy and Transport Scenarios on Key Drivers. Office for Official Publications of the European Communities, Luxembourg, p. 262.

McDowall, W., Eames, M., 2006. Forecasts, scenarios, visions, backcasts and roadmaps to the hydrogen economy: a review of the hydrogen futures literature. Energy Policy 34, 1236-1250.

Metschies, G.P., 2005. International Fuel Prices 2005. GTZ/Metschies Consult, Kelkheim, Germany, p. 114.

Planning Commission, 2006. Report of the Expert Commitee on Integrated Energy Policy. Government of India, New Delhi.

Rogner, H.-H., 1997. An assessment of world hydrocarbon resources. Annual Review of Energy and the Environment 22, 217-262.

Schultz, K.R., Brown, L.C., Besenbruch, G.E., Hamiton, C.J., 2003. Large-scale production of hydrogen by nuclear energy for the hydrogen economy. In: National Hydrogen Association Annual Conference, Washington, DC.
Shukla, P.R., Nair, R., Kapse, M., Garg, A., Balasubramaniam, S., Menon, D., Sharma, K.K., 2003. Development and Climate-An Assessment for India. UNEP, Roskilde.

Solomon, B.D., Banerjee, A., 2006. A global survey of hydrogen energy research, development and policy. Energy Policy 34, 781-792.

Stern, D.I., 2004. The rise and fall of the environmental kuznets curve, World Development 32, 1419-1439.

van Ruijven, B., van Vuuren, D.P., de Vries, B., 2007. The potential role of hydrogen in energy systems with and without climate policy. International Journal of Hydrogen Energy 32, 1655-1672.

van Vuuren, D.P., 2007. Energy Systems and Climate Policy. Department of Science, Technology and Society, Faculty of Science, Utrecht University, Utrecht, p. 326.

van Vuuren, D.P., Fengqi, Z., de Vries, B., Kejun, J., Graveland, C., Yun, L., 2003. Energy and emission scenarios for China in the 21st century - exploration of baseline development and mitigation options. Energy Policy 31, 369-387.

van Vuuren, D.P., van Ruijven, B.J., Hoogwijk, M.M., Isaac, M., de Vries, H.J.M., 2006. TIMER 2.0, model description and application. In: Bouwman, A.F., Hartman, M.P.M., Klein Goldewijk, C.G.M. (Eds.), Integrated Modelling of Global Environmental Change. An overview of IMAGE 2.4. Netherlands Environmental Assessment Agency (MNP), Bilthoven.

van Vuuren, D.P., den Elzen, M., Lucas, P., Eickhout, B., Strengers, B., 